
酸化物の影響

\author{
上島良之 $*$ 湯山英俊 ${ }^{* 2} \cdot$ 溝口庄三*3 梶岡博幸*
}

\title{
Effect of Oxide Inclusions on MnS Precipitation in Low Carbon Steel
}

Yoshiyuki Ueshima, Hidetoshi Yuyama, Shozo Mizoguchi and Hiroyuki KaJioKa

\begin{abstract}
Synopsis :
It has been known that precipitates of $\mathrm{MnS}$ become effective nuclei of intragranular ferrite during $A_{3}$ transformation and improve the ductility of steels. The objective of this work is to investigate the effect of oxide inclusions on $\mathrm{MnS}$ precipitation after solidification in order to obtain uniform distribution of precipitates. Various deoxidizing elements were added to low carbon steel melt of $1 \mathrm{~kg}$. This steel melt was solidified in an alumina crucible after some killing time. The nonmetallic inclusions were analysed by two-dimensional $\mathrm{X}$-ray microanalyser on a cross-section of the ingot specimen. Among deoxidizing elements, the number of oxide inclusions of $\mathrm{Hf}, \mathrm{Ce}, \mathrm{Y}$ or $\mathrm{Zr}$ was greater and the distribution was more uniform than that of $\mathrm{Al}$ or $\mathrm{Ti}$. The precipitation of $\mathrm{MnS}$ was followed effectively on those oxide inclusions between 1100 and $1400^{\circ} \mathrm{C}$. The kinetics of precipitation was analysed by a precipitation model taking into account solidification and $\delta / \gamma$ transformation. The low diffusivity of Mn causes the depletion of Mn around $\mathrm{MnS}$ precipitates. It was considered that this Mn depletion promoted ferrite nucleation.

Key words : diffusion; inclusion; interface; microscopy; phase transformation; precipitation; segregation; solidification.
\end{abstract}

\section{1. 緒言}

低炭素鋼の $\gamma / \alpha$ 変態において，通常は $\gamma$ 粒界から粗 大なフェライトが生成する.この時，適当な析出物が鋼 中に存在すると, これを核として微細な粒内フェライト (Intragranular Ferrite Plate, 以下 IFP と呼ぶ) が生成 し, 鋼の鞄性が向上する ${ }^{1)}$.

その IFP の生成核としては, 現在まで, REMoxysulphide- $\mathrm{BN}^{1)}, \mathrm{Ca}-$ oxysulphide ${ }^{2)}, \mathrm{TiN}^{3)}, \mathrm{TiO}^{4)}$, $\mathrm{Ti}_{2} \mathrm{O}_{3}{ }^{5)}, \mathrm{TiN}-\mathrm{MnS}-\mathrm{Fe}_{23}(\mathrm{CB})_{6}{ }_{6}{ }^{6}, \mathrm{Al}-\mathrm{Mn}$-silicate/Al$\mathrm{Ti}-$ Oxide $/ \mathrm{MnS}^{7)}$ 等, 多くの析出物が知られている.

これらの中で, $\mathrm{MnS}$ はその析出温度から適用範囲が 広いと期待されるが, 通常は凝固時に生じるミクロ偏析 部に晶出, あるいは, 析出する. しかし, ミクロ偏析部 は固溶元素の濃縮により一般的に焼入性が高くなつてお り,ここに MnS が存在しても IFP の核として有効に
作用しない。一方, TiN はミクロ偏析部に限らず固相 中に均一に析出するため， TiN を核として析出した $\mathrm{MnS}$ は IFP の核として十分に効果を発揮していると考 えられる6). しかし, TiN も $1350^{\circ} \mathrm{C}$ と比較的低温で溶 解するため, 大入熱溶接を行う場合は難点がある.

そこで本研究では，より高温で安定な酸化物に $\mathrm{MnS}$ を析出させることを考え，まず，溶鋼の脱酸過程から $\mathrm{MnS}$ の析出過程に至るまでの, 酸化物と $\mathrm{MnS}$ の晶出, 析出挙動を調べることにした.

\section{2. 実：験 方 法}

\section{$2 \cdot 1 \quad 1 \mathrm{~kg}$ インゴット凝固実験}

電解鉄 $1 \mathrm{~kg}$ を内径 $20 \mathrm{~mm}$, 深さ $70 \mathrm{~mm}$ のアルミナる つぼにれ，Ar 雾囲気下で高周波溶解した. $1570^{\circ} \mathrm{C}$ で主成分の調整を行つた後, $\mathrm{Fe}_{2} \mathrm{O}_{3} 1 \mathrm{~g}$ を添加した。 そ の後 $\mathrm{Al}, \mathrm{Ti}, \mathrm{Zr}, \mathrm{La}, \mathrm{Ce}, \mathrm{Hf}$, およびY の各種純金 昭和 62 年 4 月本会講演大会にて発表 昭和 63 年 2 月 17 日受付 (Received Feb. 17, 1988)

* 新日本製鉄(株)製鋼研究センター 工博 (Steelmaking Technology Lab., Nippon Steel Corp.)

*2 新日本製鉄(株)製鋼研究センター (現：新日本製鉄(株)大分製鉄所) (Steelmaking Technology Lab., Now Oita Works, Nippon Steel Corp.)

*3 新日本製鉄(株)製鋼研究センター Ph. D. (Steelmaking Technology Lab., Nippon Steel Corp., 1618 Ida Nakahara-ku Kawasaki 211) 
Table 1. Chemical composition of specimens for various deoxdation experiments (wt\%).

\begin{tabular}{|c|c|c|c|c|c|c|c|c|}
\hline No. & $\begin{array}{l}\text { Killing time } \\
\text { (sec) }\end{array}$ & C & Si & $\mathrm{Mn}$ & $\mathbf{P}$ & $\mathbf{s}$ & $x$ & $\begin{array}{c}\text { Total } \\
0\end{array}$ \\
\hline$A \mid-1$ & 30 & 0.096 & 0.19 & 0.93 & 0.014 & 0.004 & Al $<0.003$ & 0.0071 \\
\hline$A l-2$ & 600 & 0.087 & 0.19 & 0.95 & 0.013 & 0.004 & Al $<0.003$ & $<0.0010$ \\
\hline $\mathrm{Ti}-1$ & 30 & 0.091 & 0.21 & 0.99 & 0.014 & 0.004 & $\begin{array}{ll}\mathrm{Ti} & 0.024\end{array}$ & 0.020 \\
\hline $\mathrm{Ti}-2$ & 600 & 0.081 & 0.20 & 0.91 & 0.013 & 0.004 & 0.010 & 0.0026 \\
\hline $\mathrm{Zr}-1$ & 30 & 0.100 & 0.20 & 0.98 & 0.014 & 0.004 & 0.010 & 0.0057 \\
\hline $\mathrm{Zr}-2$ & 600 & 0.090 & 0.22 & 0.96 & 0.015 & 0.004 & 0.002 & 0.0045 \\
\hline La - 1 & 30 & 0.066 & 0.20 & 0.97 & 0.014 & 0.004 & La 0.04 & 0.0081 \\
\hline La - 2 & 600 & 0.068 & 0.22 & 0.94 & 0.015 & 0.004 & $L a<0.02$ & 0.0024 \\
\hline $\mathrm{Ce}-1$ & 30 & 0.075 & 0.20 & 0.98 & 0.015 & 0.004 & Ce $\quad 0.02$ & 0.0082 \\
\hline $\mathrm{Ce}-2$ & 600 & 0.067 & 0.21 & 0.95 & 0.015 & 0.004 & $\mathrm{Ce}<0.02$ & 0.0029 \\
\hline$H f-1$ & 30 & 0.088 & 0.19 & 0.97 & 0.014 & 0.004 & $\mathrm{Hf}<0.001$ & 0.012 \\
\hline $\mathrm{Hf}-2$ & 600 & 0.085 & 0.21 & 0.93 & 0.002 & 0.004 & $\mathrm{Hf}<0.001$ & 0.0061 \\
\hline$Y-1$ & 30 & 0.081 & 0.20 & 0.94 & 0.015 & 0.004 & Y $\quad 0.03$ & 0.012 \\
\hline$Y-2$ & 600 & 0.070 & 0.22 & 0.95 & 0.014 & 0.004 & $Y<0.02$ & 0.0020 \\
\hline
\end{tabular}

Table 2. Condition of the measurement of precitates by two-dimensional $\mathrm{X}$-ray microanalyser.

\begin{tabular}{c|c|c|c}
\hline & \multicolumn{2}{|c|}{ Identification } & \multirow{2}{*}{ Distribution } \\
\cline { 2 - 3 } & $\mathrm{Ti}$ added & $\mathrm{Zr}$ added & \\
\hline $\begin{array}{c}\text { Beam size } \\
(\mu \mathrm{m} f)\end{array}$ & 0.013 & 0.040 & 3 \\
\hline $\begin{array}{c}\text { Area } \\
\left(\mu \mathrm{m}^{2}\right)\end{array}$ & $12.8 \times 9.216$ & $40.0 \times 28.8$ & $1500 \times 1500$ \\
\hline $\begin{array}{c}\text { Integration time } \\
(\mathrm{ms})\end{array}$ & 200 & 200 & 30 \\
\hline Elements & $\mathrm{Ti}, \mathrm{Mn}, \mathrm{S}$ & $\mathrm{Zr}, \mathrm{Mn}, \mathrm{S}, \mathrm{Si}$ & $\begin{array}{l}\mathrm{Mn}, \mathrm{S}, \mathrm{Al}, \mathrm{Ti}, \mathrm{Zr}, \mathrm{La}, \\
\mathrm{Ce}, \mathrm{Hf}, \mathrm{Y}\end{array}$ \\
\hline
\end{tabular}

属をそれぞれ単独で $0.02 \%$ を目標に添加して脱酸し， 一定時間保定した後電流を切つてるつぼ中で冷却した。

酸化物量の影響を調べるため, 脱酸後の保定時間は 30 $\mathrm{s}$ と $10 \mathrm{~min}$ の二水準とした. るつほ中で冷却したイン ゴットの冷却曲線は, 熱電対測定により $1500^{\circ} \mathrm{C}$ 以上 では $8^{\circ} \mathrm{C} / \mathrm{min}, 1500 \sim 1000^{\circ} \mathrm{C}$ では平均 $35^{\circ} \mathrm{C} / \mathrm{min}$ であ つた.

実験試料の化学成分を Table 1 に示す. 次にこのイ ンゴットを縦方向に切断し, 底部から $15 \mathrm{~mm}$ の位置の 中央部から, 約 $10 \mathrm{~mm}$ 角の分析試料を採取した.この 試料は，新二次元 $\mathrm{X}$ 線マイクスアナライザー8)（以下 CMA）に供し，特性 X 線像と反射電子線像により析出 物の同定, 粒径分布の測定, 併せて, ミク口偏析を行つ た. 測定条件を Table 2 に示す.

なお, 特性 X線像による析出物の認定は次のように行

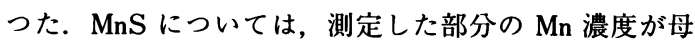
材 $\mathrm{Mn}$ 濃度の 1.32 倍以上で, かつ, $\mathrm{S}$ の X 線強度が平 均值の $5 \sigma$ 以上の部分とした $(\sigma$ は X 線強度の標準偏 差). $\mathrm{Mn}$ のしきい值 1.32 は, 連鋳鋳片の偏析部の酸腐 食像に対応した值であり, MnS は通常この偏析部に存
Table 3. Chemical composition of specimen for unidirectional solidification experiment.

\begin{tabular}{c|cccccccc}
\hline & $\mathrm{C}$ & $\mathrm{Si}$ & $\mathrm{Mn}$ & $\mathrm{P}$ & $\mathrm{S}$ & $\mathrm{Cu}$ & $\mathrm{Ni}$ & $\mathrm{Al}$ \\
\hline wt\% & 0.077 & 0.20 & 1.01 & 0.016 & 0.0043 & 0.01 & 0.01 & 0.022 \\
\hline
\end{tabular}

在する. 酸化物についても同様に, 脱酸元素の平均 $\mathrm{X}$ 線 強度の $5 \sigma$ 以上の部分とした. ただし, $3 \mu \mathrm{m}$ のビーム 径の測定でもあり，この認定方法では実際の粒子径より 大きく見積もる可能性があるので, 粒径, 個数, 生成量 の絶対值の信頼性は低い. しかし, 同一条件の測定値間 での相対的比較は十分可能である.

一方, 析出物の反射電子像では, 原子番号の大きい元 素ほど明るく見える. その明るさ（電子線の反射率）と 原子番号の間には一定の関係があり，その明るさに応じ て析出物中の相を識別した. 特性 X線像と反射電子線像 の結果を組み合わせると, 本実験で同時に存在する可能 性のある, 酸化物と硫化物すべての識別が可能である.

\section{$2 \cdot 2$ 一方向凝固実検}

電解鉄と必要な合金元素を真空溶解して鋳造した鋼塊 を, 熱間鍛造後切削加工して作成した, 直径 $15 \mathrm{~mm}$, 長さ $250 \mathrm{~mm}$ の丸棒試料を実験に用いた.この実験では， 主に, $\mathrm{MnS}$ の析出挙動を明らかにすることを目的とし， 脱酸元素は標準的な $\mathrm{Al}$ を用いた。試料の化学成分を Table 3 に示す. 一方向凝固実験の装置と方法は既報 ${ }^{9)}$ のとおりであり, 本実験での冷却速度は $27,54^{\circ} \mathrm{C} / \mathrm{min}$ とした.

一定時間引き抜いて水冷した後, 得られた試料の切断 面を CMA で分析した. 測定条件は Table 2 の右端に 示した. 析出物の認定は前述と同一条件である.

\section{3. 実 験 結 果}

\section{$3 \cdot 1 \quad 1 \mathrm{~kg}$ インゴット疑固実検}

まず, Photo. 1 に析出物の分布におよほす, 保定時 間の影響の一例を示す。雲のように見える部分が $\mathrm{Mn}$ のミクロ偏析部で, 白い点状の粒子が析出物である.

$\mathrm{Mn}$ は凝固後の固相拡散速度が小さいこと, $\delta / \gamma$ 変態に よる再分配がわずかであることから，Mnの等濃度線は 凝固中の固液界面の形状を最も良く現している ${ }^{9}$.

この観察と析出物の識別結果により, 以下のことがわ かつた。

( 1 ) Al， Tiより強脱酸元素の酸化物はミク口偏析に 無関係に均一に分散している.

( 2 ) Al， La 以外では $\mathrm{MnS}$ は酸化物と複合している のが圧倒的に多い. 
(3)複合析出物の個数は, 保定時間 $30 \mathrm{~s}$ の方が多い. なお， Laは硫化物として単独の LaS を多数形成して おり, 他の脱酸元素と挙動が異なる. 本研究では $\mathrm{MnS}$

\section{killing time}

$30 \mathrm{sec}$

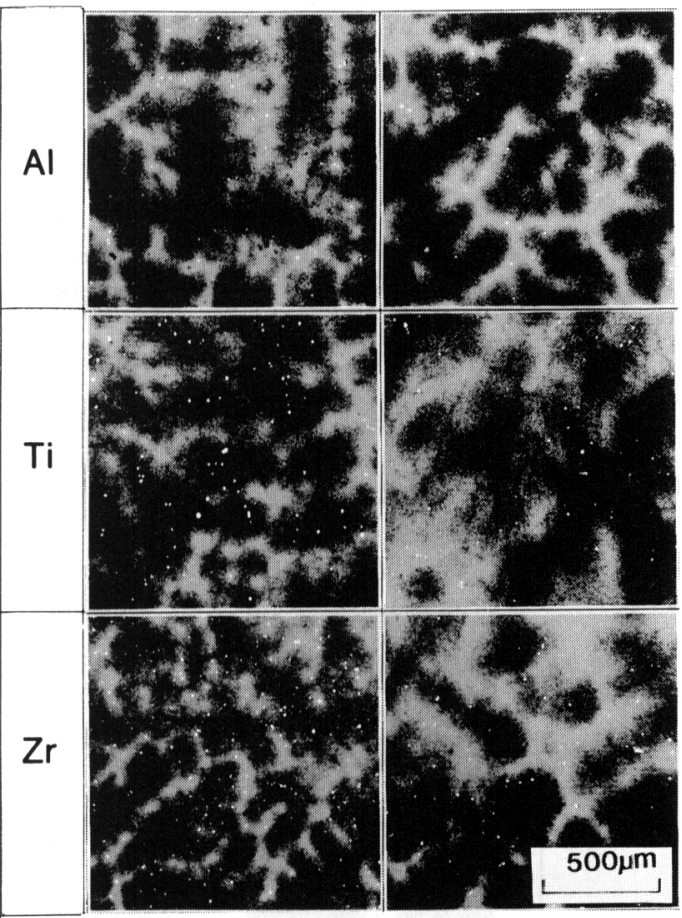

The white network structure corresponds to microsegregation of $\mathrm{Mn}$ and the white spots are precipitaes. The precipitates for $\mathrm{Zr}$ deoxidation are more numerous and uniformly dispersed

Photo. 1. Distribution of the precipitates.
の析出挙動に限定し，以後の解析では参考にとどめる.

Fig. 1(a)，（b)に酸化物の個数と粒径を示す. 脱酸元 素は脱酸力の順序 ${ }^{10)}$ に並べてある（Y と Hf は周期率 表から推定). $30 \mathrm{~s}$ 保定後の酸化物の個数は $\mathrm{Ti}$ や $\mathrm{Al}$ 脱 酸では約 $130\left(\right.$ 個 $\left./ 1.5 \times 1.5 \mathrm{~mm}^{2}\right)$ であるのに対して, その他の強脱酸元素では約 350 (個 $\left./ 1.5 \times 1.5 \mathrm{~mm}^{2}\right)$ と 多かつた。また, 粒径は前者が約 $11 \mu \mathrm{m}$ で, 後者で約 $9 \mu \mathrm{m}$ であつた.しかし， $10 \mathrm{~min}$ 保定後の酸化物個数は 脱酸力にあまりよらず, 約 80 (個/ $\left.1.5 \times 1.5 \mathrm{~mm}^{2}\right)$ と大 幅に減少した。

次に, 酸化物の個数と複合した $\mathrm{MnS}$ の個数の関係を Fig. 2 に示す. 強脱酸元素を添加した場合酸化物個数 が多く, 複合した $\mathrm{MnS} も$ 多いことは先の観察結果を裏 付けている. 酸化物個数と複合 $\mathrm{MnS}$ の粒径の関係は Fig. 3 に示す. Ti の挙動は不明であるが, その他は酸

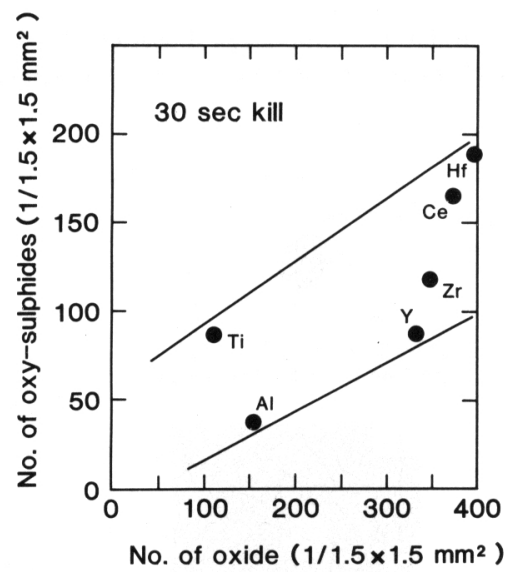

Fig. 2. Relation of the numbers of oxysulphide and oxide inclusions.
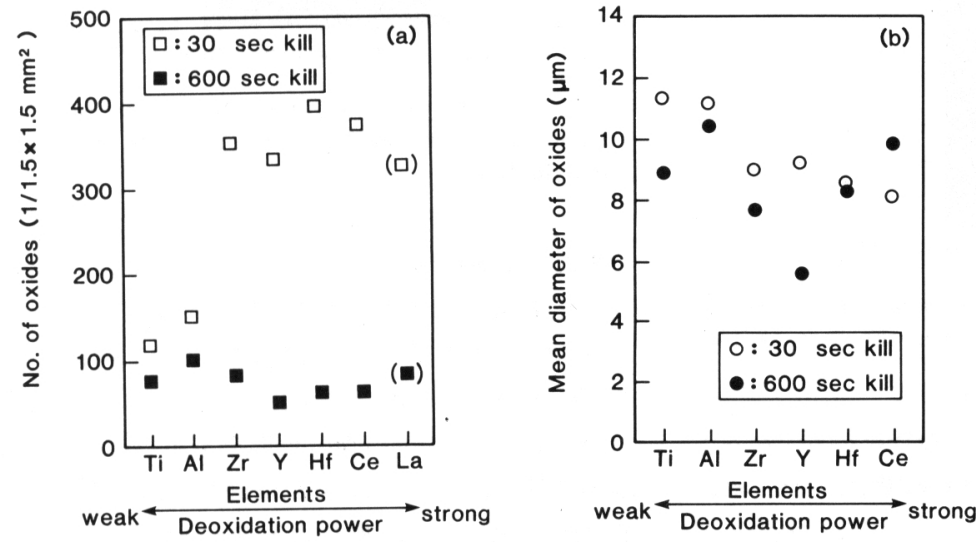

Fig. 1. Number (a) and mean diameter (b) of oxide inclusions. 


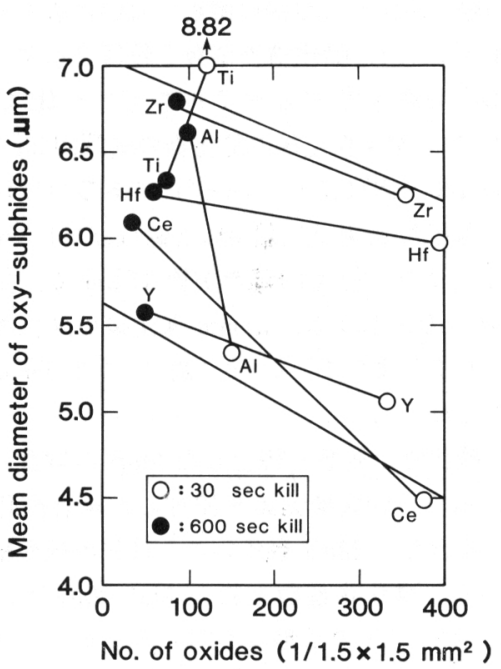

Fig. 3. Relation of the mean diameter of oxy-sulphide inclusions and the number of oxide inclusions.

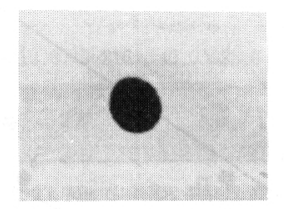

(a) Electron reflection image

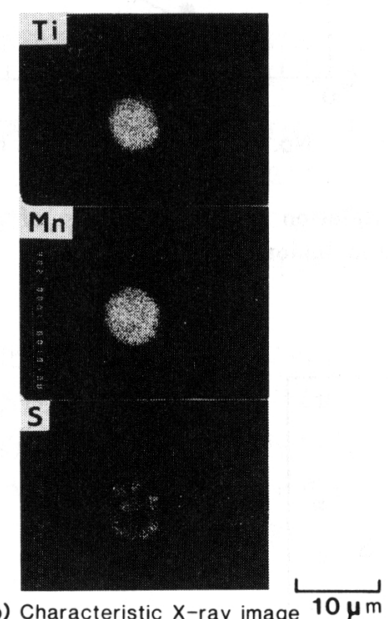

MnS precipitates forms partly on Ti-Mn complex oxide inclusion Photo. 2. Compound precipitate in the case of $\mathrm{Ti}$ deoxidation.

化物個数が多いほど，複合 $\mathrm{MnS}$ の粒径は小さくなるよ うである。酸化物と複合 $\mathrm{MnS}$ の粒径の関係には，際だ つた相関は認められなかつた。

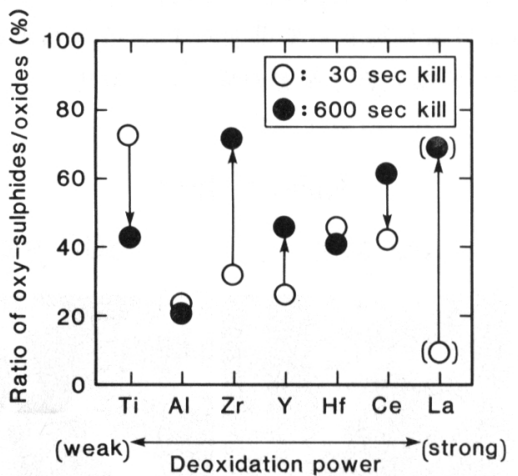

Fig. 4. Ratio of the numbers of oxysulphide and oxide inclusions for various deoxidation elements.

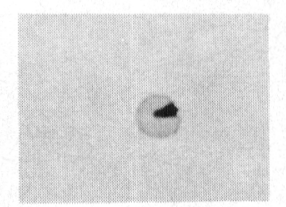

(a) Electron reflection image

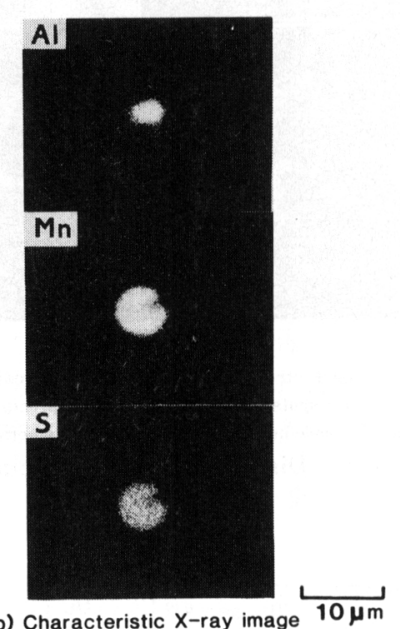

$\mathrm{MnS}$ precipitate covers partly $\mathrm{Al}$ oxide inclusion

Photo. 3. Compound precipitate in the case of $\mathrm{Al}$ deoxidation.

また，総酸化物個数のうち, $\mathrm{MnS}$ の複合した個数の 割合を Fig. 4 に示す。脱酸力にはあまり依存しないが $\mathrm{Al}$ の場合が特に低い。保定時間の影響は明確ではない が， $\mathrm{Zr}$ や Y では $\mathrm{MnS}$ の複合化がしやすいようである.

Photo. 2〜4 に析出物の形態を示す. 今回の $1 \mathrm{~kg} の$ 凝固実験では，析出形態は 2 種類に分類できる。まず $\mathrm{Ti}$ 脱酸の場合は $\mathrm{Ti}$ 酸化物と $\mathrm{MnO}$ が混在した上に, 


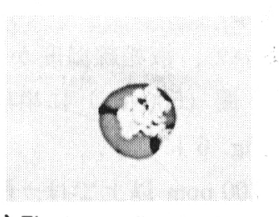

(a) Electron reflection image

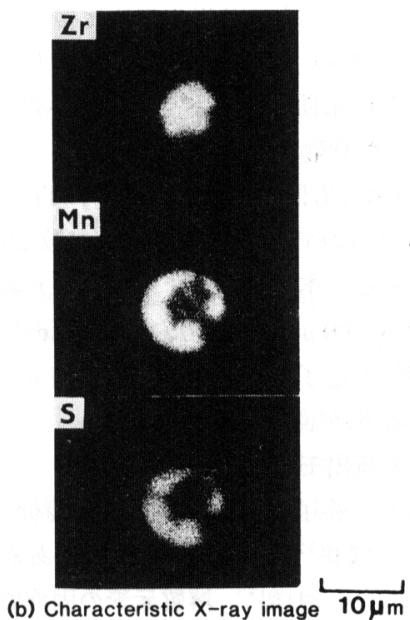

$\mathrm{MnS}$ precipitate covers $\mathrm{Zr}$ oxide inclusion

Photo. 4. Compound precipitate in the case of $\mathrm{Zr}$ deoxidation.

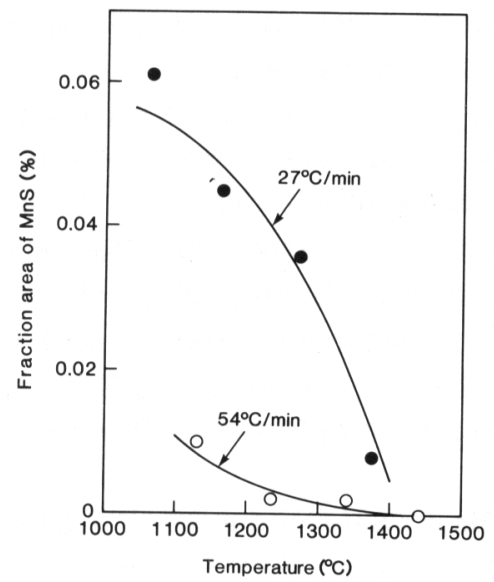

Fig. 5. Fraction area of $\mathrm{MnS}$ precipitates at various temperatures obtained in a unidirectional solidification experiment.

$\mathrm{MnS}$ が部分的に析出している (Photo. 2)。その他の脱 酸元素の場合は, 角状の酸化物のクラスターを核にして, その周囲を $\mathrm{MnS}$ が皮のように包んでいる（Photo. 3， 4),
いずれの場合も,酸化物と硫化物の結晶構造の関係や, 相互の固溶状態は明らかでない。

\section{$3 \cdot 2$ 一方向凝固実験}

この実験では, 凝固温度から $\mathrm{MnS}$ の析出温度まで, 連続的な变化を調べることができる．解析の方法はイン ゴット試験と全く同様である.

Fig. 5 は各温度での $\mathrm{MnS}$ の面積率（測定視野に占め る面積割合）を示したものである. $1400^{\circ} \mathrm{C}$ 付近の温度 で $\mathrm{MnS}$ の析出が開始し, $27^{\circ} \mathrm{C} / \mathrm{min}$ の冷却速度では $1050^{\circ} \mathrm{C}$ 付近まで増加する。一方, $54^{\circ} \mathrm{C} / \mathrm{min}$ では $\mathrm{MnS}$ の析出が極端に抑制されており, $27^{\circ} \mathrm{C} / \mathrm{min}$ の場合に比 べ, $1100^{\circ} \mathrm{C}$ でたかだか $20 \%$ の量であつた.

\section{4. 考察}

各脱酸元素によつて酸化物の分布, 個数, および, そ の後に引続く $\mathrm{MnS}$ の生成挙動に違いが見られる。すな わち, 通常の脱酸元素である $\mathrm{Al}$ に比べて $\mathrm{Ti}$ の方が, さらには， $\mathrm{Zr}$ の方が $\mathrm{MnS}$ の核生成に適している。こ の理由としては，一般的には酸化物と硫化物の界面エネ ルギーや, 結晶格子間の整合性の影響が考えられるが明 らかではない. 本実験結果からだけでは, $\mathrm{MnS}$ の付着 程度の差の原因は議論できないので, 工業的見地から重 要と思われる $\mathrm{Ti}$ と $\mathrm{Zr}$ をとりあげて凝固, 析出過程に お涑酸化物と硫化物の晶出, 析出挙動を解析する.

\section{$4 \cdot 1$ 酸化物の晶出モデル}

凝固時の溶質元素の固液分配, $\delta / \gamma$ 变態, 固相内拡散 を考慮した数学モデル9)11)に, 今回さらに, 酸化物の晶 出モデルを加え差分法によつて逐次計算する．解析した 元素は, $\mathrm{C}, \mathrm{Si}, \mathrm{Mn}, \mathrm{P}, \mathrm{O}$ と脱酸元素 $(\mathrm{Ti}, \mathrm{Zr})$ で ある.この計算方法は既報 ${ }^{12)}$ で述べた $\mathrm{MnS}$ 晶出モデ ルと基本的には同一である。 そこで，ここでは詳しい計 算手法は省略し，設けた仮定と変更点のみ述べる.

( 1 ) 六角形デンドライト凝固とし，一次枝のみ考慮す る.

(2) 固液界面， $\delta / \gamma$ 界面で，溶質元素は平衡分配する.

( 3 ) 溶質元素は液相内では均一濃度で, 固相内でデン ドライトの半径方向に拡散する。

(4)逐次計算して得られた溶質濃度を式( 1 )-( 2)に 代入して求めた液相線温度, および, $A_{4}$ 変態温度が害 験装置で与えられた温度と一致するように，固液界面と $\delta / \gamma$ 界面を移動させる。

$$
\begin{aligned}
T_{L} & =1536-78[\% \mathrm{C}]-7.6[\% \mathrm{Si}]-4.9[\% \mathrm{Mn}] \\
& -34.4[\% \mathrm{P}]-17.6[\% \mathrm{Ti}]-9.1[\% \mathrm{Zr}]\left({ }^{\circ} \mathrm{C}\right)
\end{aligned}
$$

$T_{L}$ は川和の式 ${ }^{13)} に, F e-T i, F e-Z r$ 二元系平衡状態 
図 ${ }^{14)}$ から見積もつた液相線温度降下係数を追加したも のである。

$$
\begin{aligned}
T_{A_{4}} & =1392+1120[\% \mathrm{C}]-60[\% \mathrm{Si}]+12[\% \mathrm{Mn}] \\
& -140[\% \mathrm{P}]-167[\% \mathrm{Ti}]-58[\% \mathrm{Zr}]\left({ }^{\circ} \mathrm{C}\right)
\end{aligned}
$$

$T_{A_{4}}$ の係数はすべて $\mathrm{Fe}-\mathrm{X}$ 二元系平衡状態図 ${ }^{14)}$ から決 定した。

( 5 )酸化物は液相中の溶存酸素と脱酸元素の濃度が, 式( 3 )，(4)から計算される平衡溶解度積に等しくなる ように晶出する.ここで, $\mathrm{Ti}$ 酸化物としては抽出残渣 分析により, $\mathrm{Ti}_{2} \mathrm{O}_{3}$ であることを確認している.

$$
\begin{aligned}
& 2[\mathrm{Ti}]+3[\mathrm{O}]=\mathrm{Ti}_{2} \mathrm{O}_{3} \\
& \Delta G^{\circ}=-256193+82.6 \mathrm{~T} \quad(\mathrm{cal}) \\
& {[\mathrm{Zr}]+2[\mathrm{O}]=\mathrm{ZrO}_{2}} \\
& \Delta G^{\circ}=-194649+56.1 \mathrm{~T} \quad \text { (cal) }
\end{aligned}
$$

計算に用いた $\mathrm{O}, \mathrm{Ti}, \mathrm{Zr}$ の平衡分配係数 $K$ と拡散係数 $D$ は Table 4 に示す.その他の元素については既報9

Table 4. Physical properties for the numerical calculation.

\begin{tabular}{cllcc}
\hline elements & $K^{\delta / L}$ & $K^{\mathrm{V} / \delta}$ & \multicolumn{1}{c}{$D^{\delta}\left(\mathrm{cm}^{2} / \mathrm{s}\right)$} & \multicolumn{1}{c}{$D^{\mathrm{V}}\left(\mathrm{cm}^{2} / \mathrm{s}\right)$} \\
\hline $\mathrm{O}$ & 0.022 & 0.025 & $0.0371 \exp (-23050 / R T)$ & $5.75 \exp (-40300 / R T)$ \\
$\mathrm{Ti}$ & 0.40 & 0.3 & $68 \exp (-62400 / R T)$ & $0.15 \exp (-60000 / R T)$ \\
$\mathrm{Zr}$ & 0.032 & 0.5 & $25.6 \exp (-57600 / R T)$ & $10.8 \exp (-69600 / R T)$ \\
\hline
\end{tabular}

$K^{\delta / L}$ or $K^{\gamma / \delta}:$ Equilibrium distribution coefficient $D^{\delta}$ or $D^{\gamma}$ : Diffusion coefficients in $\delta$ or $\gamma$ phase

$K$ for $\mathrm{O}$ and $\mathrm{Ti}$ (Ref. 16) $K$ for $\mathrm{Zr}$ (Fe- $\mathrm{Zr}$ phase diagram in Ref. 14) $D$ for $O$ (Ref. 17) $D$ for Ti Ref. 18) $D$ for $\mathrm{Zr}$ (estimated from selfdiffusion coefficient in $\delta$ - and $\gamma-\mathrm{Fe} D_{\mathrm{Zr}} / D_{\mathrm{Fe}}$ (Fig. 12 in Ref. 18)

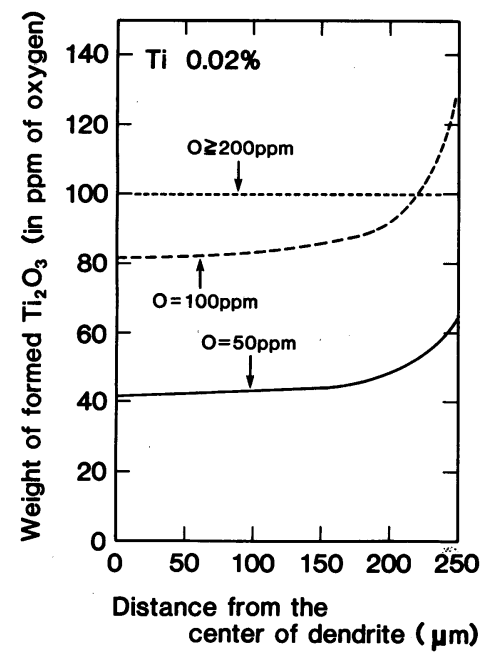

Fig. 6. Distribution of Ti-oxide calculated by a mathematical model.
に示したとおりである.

まず $\mathrm{Ti}$ 脱酸において，液相線温度から凝固終了温度 までにデンドライト間 $(500 \mu \mathrm{m})$ に生成する酸化物量 分布の計算結果を Fig. 6 に示す.

脱酸前酸素量が $200 \mathrm{ppm}$ 以上では，酸化物の分布は 均一となる。これはほとんどの酸化物は，いわゆる一次 脱酸で生成し，凝固中に晶出する酸化物は極めてわずか となるためである。一方，脱酸前酸素量が 100 と 50 ppm では, 凝固末期のデンドライト間への $\mathrm{Ti}$ と酸素の 偏析に伴つて酸化物量が增加する.

$\mathrm{Zr}$ 脱酸の場合も同様に計算したが, Tiよりもはるか に脱酸力が強いので，脱酸前酸素量が数 $\mathrm{ppm}$ でも一次 脱酸で完了する. 本実験条件では，脱酸元素添加前の溶 存酸素量は約 $300 \mathrm{ppm}$ であり, Ti と Zr どちらの場合 も一次脱酸で完了し，酸化物の分布が均一になる Photo. 1 の結果が説明できる.

\section{$4 \cdot 2 \mathrm{MnS}$ の析出モデル}

凝固開始から終了温度までのミク口偏析と $\mathrm{MnS}$ の析 出の計算は，既報 ${ }^{12)}$ のモデルと同一である．前述の酸 化物生成モデルと同様に，溶質元素の固液間平衡分配， $\delta / \gamma$ 間平衡再分配，固相内拡散をすべて考慮している. 各温度での $\mathrm{MnS}$ の析出量を計算するために設けた仮定 のみ説明する.

( 1 ) $\mathrm{MnS}$ の析出は, 固相内の $\mathrm{Mn}$ と $\mathrm{S}$ の濃度積が平 衡溶解度積に達した時に開始し, 固相中の $\mathrm{Mn} と \mathrm{~S}$ の 拡散律速により球状に成長する。

( 2) MnS の析出サイトは, デンドライト内に 3 次元 的に等間隔に与える. 実際にはデンドライト内の各節点 領域と同一の溶質濃度を持つ球体を考え, その中心に析 出サイトを設ける.この球の直径が析出間隔に相当する.

( 3 ) $\mathrm{MnS}$ の平衡溶解度積は WRIED $5^{19)}$ TURKDogAN $ら^{20)}$ の式に, Si 濃度の補正項を加えた次式で計算する. ここで, $\mathrm{S}$ に対する $\mathrm{Si}$ の相互作用助係数として, 固体 鉄中での值が無いので溶鉄中の值 $e_{\mathrm{S}}^{\mathrm{Si}}=0.07^{21)}$ を用い た.

$$
\begin{aligned}
& \log [\% \mathrm{Mn}][\% \mathrm{~S}](\delta)=-10590 / T+4.302 \\
& -0.07[\% \mathrm{Si}] \\
& \log [\% \mathrm{Mn}][\% \mathrm{~S}](\gamma)=-9020 / T+2.929 \\
& -(215 / T+0.097)[\% \mathrm{Mn}]-0.07[\% \mathrm{Si}]
\end{aligned}
$$

その他計算に使用した物性值は前述のとおりである。一 例として析出間隔を $150 \mu \mathrm{m}$ とした場合の, 各温度での $\mathrm{MnS}$ の生成量の計算結果を Fig. 7 に示す. 冷却速度は 一方向凝固実験条件にあわせて $27,54^{\circ} \mathrm{C} / \mathrm{min}$ とした. この計算結果からは冷却速度によらず, $\mathrm{MnS}$ は 


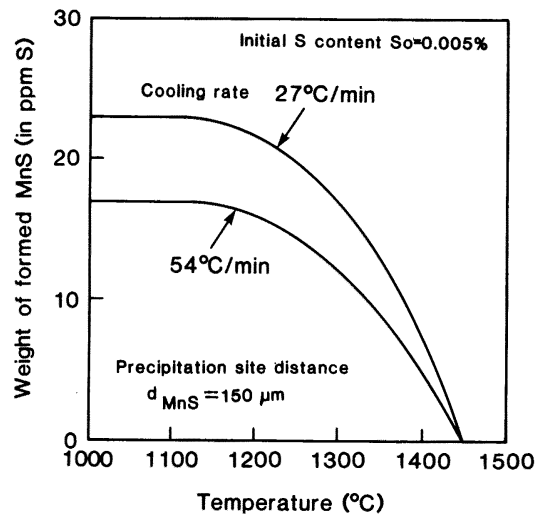

Fig. 7. Calculation of $\mathrm{MnS}$ precipitation at various temperatures by a diffusion model.

$1450^{\circ} \mathrm{C}$ で析出を開始し, $1150^{\circ} \mathrm{C}$ で完了することにな る. Fig. 5 に示した $27^{\circ} \mathrm{C} / \mathrm{min}$ での実測值と比較すると, 析出開始点から急増する領域の傾向はほほ一致してい る.

一方, $54^{\circ} \mathrm{C} / \mathrm{min}$ の計算值は $27^{\circ} \mathrm{C} / \mathrm{min}$ に比べて, 析 出量は䄪 2 割低下する程度であるが, 実測值は 8 割の低 下となつている. また, $1150^{\circ} \mathrm{C}$ 以下でも析出がさらに 進行するようであり両者は一致していない.この原因と しては, 特性X 線による析出物の面積率の測定におよほ す粒径の影響, $\mathrm{MnS}$ と地鉄の界面での平衡からのずれ 等が考えられるが明確ではない. いずれにせよ, 冷却速 度が大きくなると, $\mathrm{MnS}$ の生成量はこの計算から予想 されるよりも，かなり少なくなるようである.

さらに $1000^{\circ} \mathrm{C}$ まで冷却した時のデンドライト間の $\mathrm{MnS}$ 生成量分布も計算した. 析出核としての酸化物が 均一に分散した場合，デンドライト内の位置によらず， $\mathrm{MnS}$ はほほ均一に分布する結果が得られた。この計算 結果は, Photo. 1 に示したように $\mathrm{Ti}$ や $\mathrm{Zr}$ の場合, 複 合 $\mathrm{MnS}$ が均一に分布することを裏付けている.

酸化物の個数は $\mathrm{MnS}$ の析出サイトの間隔を決める. そこで, 測定した視野の $1.5 \times 1.5 \mathrm{~mm}^{2}$ に存在する, 酸 化物の個数 $(n)$ に応じてその間隔 $\left(d_{\mathrm{MnS}}=\sqrt{1.5 \times 1.5 / n}\right)$ を求め, $\mathrm{MnS}$ の粒径を計算した. Fig. 8 に $27^{\circ} \mathrm{C} / \mathrm{min}$ で $1000^{\circ} \mathrm{C}$ まで冷却した時の $\mathrm{MnS}$ 粒径におよぼす酸化 物個数の影響を示す. 酸化物個数が多いほど，析出サイ トの間隔が短かくなるので, 個々の硫化物の成長に必要 な $\mathrm{Mn}$ と $\mathrm{S}$ の供給が不足し, 粒径が小さくなる.この 計算結果は Fig. 3 の実験結果の傾向と一致している.

\section{$4 \cdot 3$ IFP 生成機構}

一般に $\gamma / \alpha$ 変態の核としては粒界が支配的であるが,

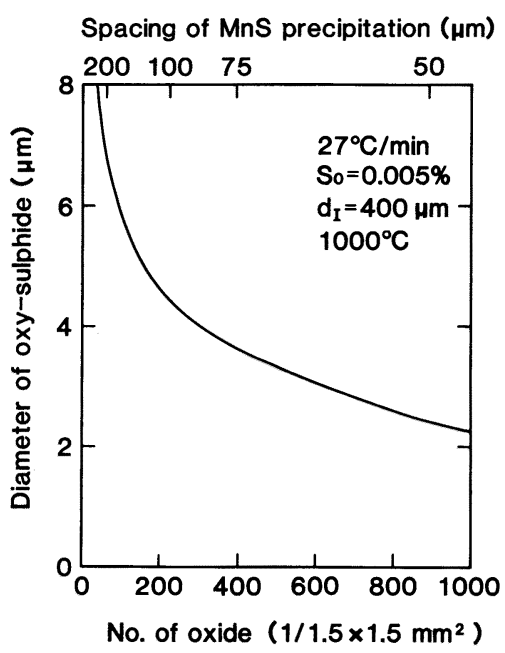

$d_{\mathrm{I}}$ : Primary dendrite arm spacing

Fig. 8. Calculation of the diameter of oxysulphide inclusion as a function of the number of oxide by a diffusion model.

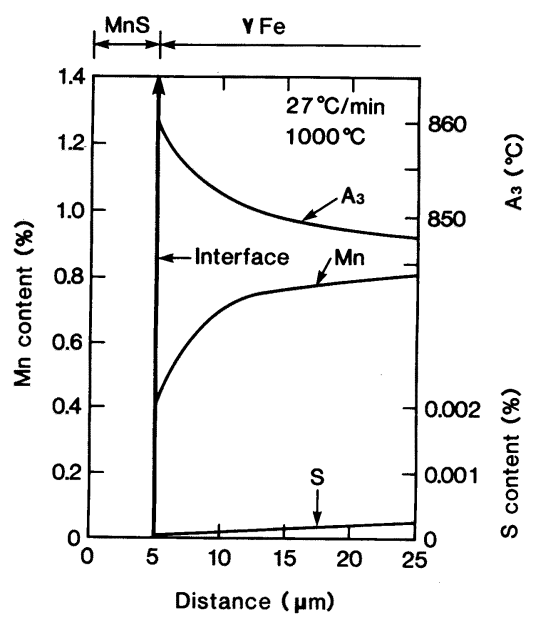

Fig. 9. Calculation of the depletion of $\mathrm{Mn}$ around $\mathrm{MnS}$ precipitate by. a diffusion model and $A_{3}$ temperature.

析出物も関与している. IFP の生成メカニズムとして は, 析出物の周囲にできる炭素の欠乏層 ${ }^{6)}$ や, 酸化物之 地鉄の結晶間の整合性 ${ }^{422)}$, 酸化物の化学組成の影響 ${ }^{23)}$ 等が検討されているが，まだよく分かつていない.

一方，著者らは低炭素硫黄快削鋼中に生成した $\mathrm{MnS}$ にの周用に，Mnの欠乏層を見出しており ${ }^{12)}$ ，これが IFP の核となる可能性に注目した. 
そこで, 本実験条件における $\mathrm{MnS}$ の周囲の $\mathrm{Mn}$ 濃度 分布を計算した. Fig. 9 は冷却速度 $27^{\circ} \mathrm{C} / \mathrm{min}$ での結果 である， $\gamma$ 鉄中の $\mathrm{Mn}$ の拡散は $\mathrm{S}$ より遅いので，図の ように $\mathrm{Mn}$ の欠乏層が生成する。このような $\mathrm{Mn}$ 濃度 の変化に対応して $A_{3}$ 変態温度 ${ }^{24)}$ が図のように上昇し, $\mathrm{MnS}$ の境界から $\alpha$ 鉄が生成する可能性も十分考えられ ることがわかった．しかし，析出物の周囲に Mn 欠乏 層を検出できなかつた報告7もあり，今後さらに実験的 に証明する必要がある。

\section{5. 結言}

溶鋼中にあらかじめ生成させた酸化物を核として, $\mathrm{MnS}$ を析出させる研究を行つた結果, 以下の結論が得 られた。

( 1 ) $\mathrm{Ti}_{2} \mathrm{O}_{3}, \quad \mathrm{Al}_{2} \mathrm{O}_{3}, \quad \mathrm{ZrO} \mathrm{rO}_{2}, \mathrm{HfO}_{2}, \quad \mathrm{Y}_{2} \mathrm{O}_{3}, \mathrm{Ce}_{2} \mathrm{O}_{3}$ を 核として $\mathrm{MnS}$ が複合析出する.

( 2 )強脱酸元素, 特に, Hf, Ce, Zr, Y 添加材では, 酸化物個数が多く, 複合 $\mathrm{MnS}$ の個数も多かつた.

( 3 ) $\mathrm{MnS}$ は約 $1400^{\circ} \mathrm{C}$ から析出を開始し, 析出量は 約 $1050^{\circ} \mathrm{C}$ まで増加した.

(4)モデル計算によると, MnS の周囲の $\gamma$ 鉄中に $\mathrm{Mn}$ の欠乏層が生成し， $A_{3}$ 温度の上昇をもたらして $\alpha$ 鉄の核になる可能性がある.

本研究は, 新日鉄顧問東北大学名誉教授不破祐博士, および，同京都大学名誉教授高村仁一博士に，種々議論 していただいたことを記して深く感謝します。また， CMA の測定に関しては, 新日鉄分析研究センター, 浜 田広樹氏の御協力に感謝します。

\section{文献}

1 ）船越督巳, 田中智夫, 上田修三, 石川正明, 腰塚典明, 小林邦彦: 鉄と鋼, 63 (1977), p. 303
2 ) 中西睦夫, 小溝裕一, 瀬田一郎, 中村昌明, 斎藤康之: 住友金属, 35 (1983), p. 133

3 ) 伊藤慶典, 中西睦夫: 溶接学会誌, 44 (1975), p. 815

4 ) 森 直道, 本間弘之, 大北 茂, 若林正邦: 溶接学会誌, 50 (1981), p. 174

5 ) 本間弘之, 大北 茂, 若林正邦, 松田昭一: 鉄と鋼, 72 (1986), S 625

6 ) 大野恭秀, 岡村義弘, 松田昭一, 山本広一, 向井俊夫: 鉄と鋼，73 (1987), p. 1010

7 ) R. A. Ricks, P. R. Howell and G. S. BARRITE: J. Mater. Sci., 17 (1982), p. 732

8 ) 田口 勇, 浜田広樹, 谷誠一郎: 製鉄研究 (1984) 313, p. 93

9 ) $Y$. Ueshima, $S$. Mizoguchi, $T$. Matsumiya and $H$. KaJioka: Metall. Trans. B, 17 (1986), p. 845

10）第 3 版鉄鋼便覧 I（日本鉄鋼協会編）（1981）, p. 7，8, p. 166 [丸善]

11）上島良之, 小松伸行, 溝口庄三, 梶岡博幸: 鉄と鋼, 73 (1987), p. 1551

12）上島良之, 磯部浩一, 溝口庄三, 前出弘文, 梶岡博幸: 鉄と鋼, 74 (1988), p. 465

13）第 3 版鉄鋼便覧 I（日本鉄鎆協会編）（1981），p. 205 [丸 善]

14) O. KUBACHEWSKI: Iron-Binary phase Diagrams (1982) [Springer Verag]

15）第 3 版鉄鋼便覧 I（日本鉄鋼協会編）(1981），p. 15, p. 19 [丸善]

16）第 3 版鉄鋼便覧 I（日本鉄鋼協会編）（1981）, p. 193, p. 194 [丸善]

17) $H$. BESTER and $K$. $W$. LANGE:Arch. Eisenhüttenwes., 43 (1972), p. 207

18）及川 洪: 鉄と鋼, 68 (1982), p. 1489

19) H. A. WriED and H. Hu: Metall. Trans. A, 7 (1976), p. 711

20) E. T. Turkdogan, S. Ignatowicz and J. Pearson: J. Iron Steel Inst., 180 (1955), p. 349

21）第 3 版鉄鋼便覧 I（日本鉄鋼協会編）（1981）, p. 23 [丸善]

22) M. Ferrante, $K$. AKune and M. Odainai: J. Mater. Sci., 22 (1987), p. 351

23) $A . R$. Bhatti, $M$. E. Saggese, $D N$. Hawkins, $J . A$. WHITEMAN and $M$. S. GoLDING: Welding Research Supplement, Weld. J., 63 (1984), p. 224-s

24）第 3 版鉄鋼便覧IV（日本鉄鋼協会編）（1981），p. 21 [丸善] 